\title{
Can Japan Make What They Have Planned?
}

\author{
Can Japan Make What They Have Planned?
}

野尻 浩之

東北大学金属材料研究所

Hiroyuki Nojiri

Institute for Materials Science Tohoku University

\section{0}

\begin{abstract}
The proposal of "High Magnetic Field Neutron Scattering for J-PARC" has been presented. The present status and the future expectation for different types of high magnetic field generators have been examined. It is concluded that a pulsed field can be the cutting edge of such science. It might be the realistic "scientific case" for a steady field case.
\end{abstract}

Keywords: high magnetic field, spin science, pulsed magnetic field

1.はじめに

強磁場は電子のスピンや軌道運動に直接結合す る制御性の高い外部場であり，今日では物性研究 に不可欠になっている。しかしながら，ゼロ磁場 で行われている高度の研究手法の展開と比べれ ば，強磁場中の実験には様々な制約があり，測定 手法としての現状はまだ発展途上にあると言える だろう。特に, 超電導磁石では到達できない $20 \mathrm{~T}$ （テスラ）以上の領域はパルス磁場という時間変 化する強磁場を用いる事から，技術的にもフロン テイアである．もし，現在ゼロ磁場で行われてい るような多様で精緻な実験手法が, 非常に強い磁 場の中でも同様の質を保ちながら出来るようにな れば, 研究の飛躍的な発展が期待できる. 最近急 速に進展しているパルス磁場と放射光 X 線を組み 合わせた実験はその良い例である [1].

では中性子散乱はどうであろうか? 磁性研究の 必須の道具である中性子散乱において強磁場の利 用は $\mathrm{X}$ 線以上に強く求められているところであ る. 現時点では, 定常磁場を用いた実験では八ー ンマイトナー研究所が一歩抜きんでていると言え るだろう。パルス磁場に関しては，日本のグルー プは 1986 年頃から既に繰り返しパルス磁場を用 いた実験をつくばの KENS で開始し，一定の成功 を収めているが, ビームの強度が弱く, 先駆的で あっても行えることは初歩的な段階に止まるとい うのが客観的な評価ではないかと考えられる [2].

しかしながら，誤解を恐れずに言えば，この現 状は強磁場コミュニティの実力不足というわけで はなく，日本の中性子源が ILL や ISIS といった世 界のトップより劣っている事が主な原因である事 も述べてきたい. 少なくともパルス磁場と中性子 やX 線の組み合わせに扮いては, 特に技術的な側 面においては日本のグループは世界でトップの位 置にいると評価されている。例えば，パルス磁場 中の X 線実験は, ESRF の次期計画において重要
な位置づけをされているが，彼らが計画している ことの多くを既に日本の強磁場グループは実際の 実験として実現しており，その先駆性は高く評価 されている。この 11 月に Grenoble で開催された "Workshop on Synchrotron Applications of High Magnetic Fields”において聞いた“Japan has done what we planned” という彼らの感想は, 実感がこ もっている。もちろんサイエンスは, 多少の先行 などすぐに逆転される世界であり，これからが本 勝負であることはいうまでもないが，世界の中で の先駆性の貴重さは強調しておきたい.

これからの事に目を向けると, J-PARCのビー 厶供給が始まろうとするこの時期に，これまでの 日本の資産と経験を生かして, どのように本格的 な研究の展開を図るかがいよいよ問われている. 強磁場中性子散乱に関連する磁場発生マグネット の現状や可能性に関しては, 既に本誌において金 道氏により詳細に述べられているが，本稿では， J-PARC に対して提案している強磁場中性子散乱 装置提案に関して紹介し, 実際に日本に扔ける強 磁場中性子散乱実験に対して，この提案の代表者 としてどのような戦略やロードマップを考えてい るのかを説明する事を主な目的としたい[3].

\section{2. 強磁場中性子散乱の意義}

強磁場中性子散乱の意義に関しては，様々な所 に述べられているので，ここではごく一般的にそ の意義を述べるにとどめたい。広い意味での磁性 および関連現象をスピン科学と呼ぶとすると，そ の柱はスピンと物質機能の間の相関の解明, 特に その基礎となる電子状態とスピン状態の間の相関 の理解である。これを知ることで電子状態をスピ ン制御する道が切りひらかれる。

通常ゼーマン効果は小さい摂動と考えられてい るが，磁場の物質への影響は，電子がひしめきあ い互いに強く相互作用し合う強相関物質等では顕 
著となり, 電子のもつ電荷とスピンの自由度の強 い結合が梃子となりスピン偏極の効果を数十倍に 増大させる. スピン偏極で結晶構造まで改変され る巨大磁気抵抗効果はその例である。このような 物質では電子やスピンはもはやばらばらではな く, 集団として新しい相を形成する. 強磁場によ り誘起される様々な相の起源を解明し，その制御 原理を確立することは物質科学の重要な課題であ る。これらの相の本質に迫るのには, 超強磁場中 性子散乱の実現が極めて有用である事は論をまた ない。より具体的な研究の課題に関しては, 提案 書をご覧頂きたい [3].

\section{3. 様々な強磁場発生装置の比較}

一言に強磁場中性子散乱装置といっても磁場の 範囲や発生方法は多様である，基本的には，超電 導磁石，ハイブリッド磁石，パルス磁石の三つに 分類できる．以下ではこれに関して順次検討する が，ここで初めに断っておきたいのは，この三つ はどれも必要なものであって, どれが最も適して いるのかを選択する議論をする事はあまり賢明で ない。むしろ，まず何から始めるのが良いのか, すなわち順番あるいは戦略を議論することが本稿 の目的である。

\section{1. 超電導磁石}

現時点で強磁場下の中性子散乱といえば $99.9 \%$ 超電導磁石の利用である。ソレノイド型に限れば オックスフォードや JASTEC が $20 \mathrm{~T}$ の磁石を販売 しており，前者は経験に裏打ちされた取り扱い易 さに, 後者はコンパクトさと安定度に優れている. これらは液体へリウムを用いる通常型の超電導磁 石であるが，最近では高温超伝導の電流リードを 用いて熱流入を押さえることで，冷凍機で冷却で きるクライオフリー超電導磁石が開発され，メン テナンスの容易さからあまり強くない磁場の実験 において多用されている. 原子力機構の JRR-3で

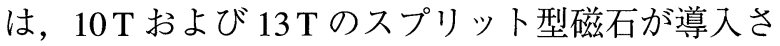
れて多くの実験に使用されている.このタイプの

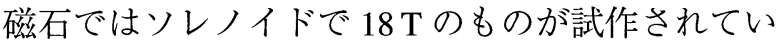
る. 従って J-PARCで初期から使用するとすれば,

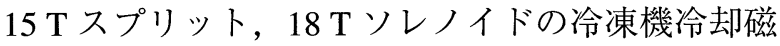
石を用意するのが望まれる。

これより強い磁場に関して言えば，NMR 用に $20 \mathrm{~T}$ 以上のものが制作されているが，磁場を頻繁 に掃引して実験を行うといった目的には適してい ない. $25 \mathrm{~T} \sim 30 \mathrm{~T}$ の超電導磁石に関しては，まだ 線材開発の段階であり, 可否も含めて目処がつく のには最低でも 5 年程度の時間が必要である。現 在このような認識の元に東北大学金属材料研究所 と物質・材料機構の強磁場施設の間で覚え書きが 取り交わされて, 次世代の超電導磁石の線材開発 が行われている。線材開発においては，単に臨界 磁場や臨界電流だけでなく, 非常に強い電磁力に よるコイルのストレスやそれに起因する性能低下 にどのように対処するのかといった事も問題にな る. 従って, $20 \mathrm{~T}$ 以上の超電導磁石の導入は, $\mathrm{J}-$
PARC の完成後の整備の中で検討をしてゆくべき 事項である. しかしながら将来磁場を使用するこ とを見込まれる分光器においては, 超電導磁石の 設置において問題となる漏洩磁場に関して予め考 えておくことが望ましいと考えられる。また，今 後より広い分野のユーザーを引きつけようとする ならば，試料環境を統合的に扱う部署を施設とし て持つことは必須である事を付け加えておきた い.このような機能のあるなしは, 直に競争力に 響いてくる。

\section{2. ハイブリッド磁石}

超電導磁石は, 現状では $20 \mathrm{~T}$, 今後 10 年を考 えても $30 \mathrm{~T}$ 以下に止まることは明らかである. 従 ってこれ以上の定常磁場においては水冷磁石と組 み合わせたハイブリッド磁石が必要となる. 現在 は水冷磁石単体で $33 \mathrm{~T}$ 程度が, 八イブリッド磁石 で $45 \mathrm{~T}$ が世界記録であるが，そのためには 20 $\mathrm{MW}$ を上回る電力を必要とする。東北大の $30 \mathrm{~T}$ 八

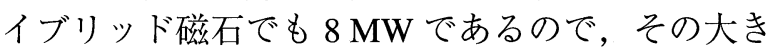
さは想像できるであろう。

現在ハイブリッド磁石の導入を具体的に進めて いるのはドイッのハーンマイトナー研究所である が, 彼らはハイブリッド磁石の超電導磁石と水冷 磁石で電源を共用する直列方式の導入を計画して いる。この形のハイブリッド磁石はアメリカ国立 強磁場研究所が設計したものであるが, その特徴 は超電導磁石の電流が $20 \mathrm{KA}$ という非常に高電流 になることで，どこまで実現可能なのかは未だ完 全に確立したわけではない.ちなみにハーンマイ トナー研究所の第一期計画では最高磁場 $25 \mathrm{~T}$, 散 乱角 30 度のソレノイド型のコイルが計画されて おり，8MW の電力で 5000 時間の使用（うち $70 \%$ が最高磁場）で, 年間の冷却水と電気の運転コス 卜は 2 億円程度と推測されている。建設費は 10 億円程度である. 日本とは電力事情が異なるので 簡単に比較はできないが, 同様のスペックであれ ば, 運転経費は 3 4 億程度, 建設費は 13 億程度 であろう。ただし，ハイブリッド磁石は巨大にな るので，ガイドホールにそのまま設置するわけに はいかずビームラインの延長や専用の建家が必要 になる．建設費をどう区面するかは大きな問題で あるが，運転経費も少なくない，運転経費を減ら す方法としてはマグネットのコンパクト化や通常 は $10 \mathrm{~T}$ 以下の超電導磁石部で発生する磁場の割合 を高くすることが考えられるが, 磁場が 15 テス ラ程度であっても, 口径の大きなハイブリッド磁 石では電磁力が大きくなるので容易ではない. ど こまでコンパクトなハイブリッド磁石が実現でき るかは, 今後の超電導磁石の開発にかかっている. さらにこのようなハイブリッド磁石を幾つもの分 光器に設置することは現実的でないので, どのよ うな分光器にするのかの検討も必要である。また 投資が巨額になるので，どのような成果が期待さ れるのかの検討も必要となる。これらの事を踏ま えるとハイブリッド磁石は, $30 \mathrm{~T}$ 以上の定常磁場 としては唯一の選択肢であるが, どのような形で 

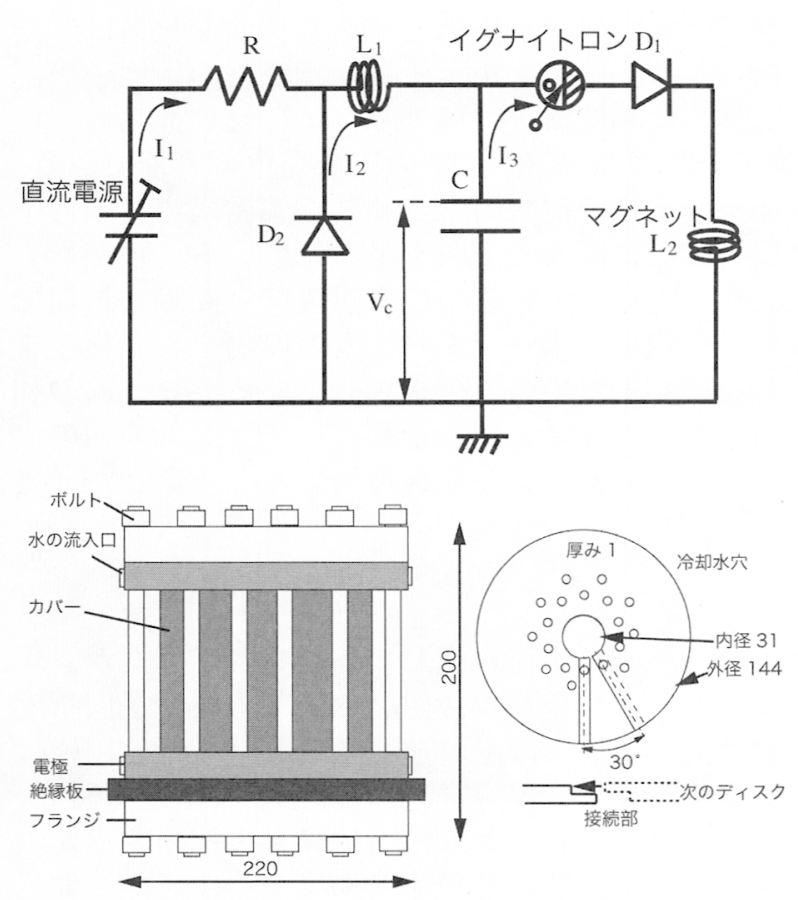

Fig.1 Circuit and magnet for repeating pulsed magnetic fields.

実現するかを検討するにはまだ時間を要すると考 えられる。

\section{3. パルス磁石}

パルス磁石は，純粋に技術的に考えれば，ある 程度確立しており，様々な R\&D は必用とされる ものの, 現時点で直ぐに実験が出来る事, 磁場と しても50〜60 T という他の手法では不可能な領 域が実現できることは大きな魅力である。

パルス磁石には通常の単発型のパルス磁石と水 冷式の磁石により繰り返して磁場を発生する繰り 返し型の 2 種類がある。後者は，つくばの KEK に扔いて 10 年以上前から実験が行われ, 最高で $25 \mathrm{~T}$ までの実験が行われてきた. Fig.1にこの方式 の電源の回路図と磁石の図を示す。スペックとし ては, パルス幅が $1 \mathrm{~ms}$, 繰り返しは磁場によるが $2 \sim 10$ 秒程度である。中性子散乱としてはパルス 中性子であるので, いわゆる白色中性を用いた飛 行時間法で測定を行っている. KENS の場合はつ ラックスが弱いために一つのピークを一つの磁場 で測定するのに必用な磁場の発生回数は典型的に は5 $5000 \sim 10000$ 回程度である。一方, 単発型のパ ルス磁場を定常炉の中性子を組み合わせて 30 $40 \mathrm{~T}$ の測定を可能にする試みが最近行われてい る. $10 \mathrm{~ms}$ 程度のパルス磁場とした場合 3 号炉で 100 発程度の積算回数が想定されている。これら 2 種類の方法はパルス磁場といえども, かなり異 なっており，場合によって使い分けることが必用 となる。目安としてデー夕積算に必用となる磁場 発生回数が 100 回程度までは単発パルス磁場が, それ以上の場合は繰り返しパルス磁場が適してい ると考えられる。

繰り返しパルス磁場の特徵は, 水冷型の磁石を 用いることで数秒の短い繰り返しが可能な点であ
るが，達成できる磁場の強さには限界がある。一 般に強磁場コイルでは流れる電流とその電流が作 る磁場の間の相互作用によりコイルを変形するマ ックスウエル応力が発生する。強い磁場を発生す るためには，コイルを多層化して，内側のコイル の電流を減らすことで，発生する磁場を同じに保 ちながらマックスウエル応力を線材の強度以下に 抑えるように工夫する。これに対して 1 層式のコ イルでは，作られる磁場は全て自分の電流で作る ので, 極めて大電流のコイルにならざるを得ない. 具体的には $30 \mathrm{~T}$ の磁場を作るため 1 層式のコイル では $30 \mathrm{kA}$ 程度の大電流が必用とされる。KEK で 実験に使用された磁石は Fig.1のようにビッター 板という径方向に肉厚の薄板を螺旋状に重祮たも のであり, 肉厚の金属で出来た螺旋であるので, 多層化は困難である。その最大の理由はパルス磁 場では表皮効果のために肉厚の金属の螺旋の外に 加えた磁場はシールドされてしまうという事があ る。繰り返しパルス磁場でより強い磁場を発生す るためには，巻き線による薄肉の螺旋型単層ソレ ノイドを同心円状に多数配置して多層化する事が 考えられるが，この場合それぞれのソレノイドを 独立に支える方法や冷却の仕方など，様々な新し い要素の検討が必要となる。従って,これまでの 繰り返しパルス磁場の技術は根本的な再検討が必 用であると考えるべきである。

これに対して単発型のパルス磁場発生技術はこ れまでの長い経験でかなり完成されており, ソレ ノイドで $50 \mathrm{~T}$ であれば数千回の磁場発生が可能で ある. $40 \mathrm{~T}$ 以下であれば, さらの多数回の磁場発 生が可能である。既に金道らはX線用のスプリッ 卜磁石で $40 \mathrm{~T}$ を超える磁場発生を可能にして拧 り, 中性子でも単結晶を用いた回折実験において は，この方式をそのまま使用することが出来る。

パルス幅は電源にもよるが, 現在特定領域“強 磁場スピン科学”で J-PARC 用に導入が予定され ている電源においては $10 \sim 30 \mathrm{~ms}$ のパルス幅が可 能であり，パルス中性子の繰り返し周波数を考え れば，多数のピークを同時に測定することが期待 できる。実験に必用とされる磁場発生回数に関し ては強度がKEKの 100 倍以上であること, さら に磁気散乱に有利な冷中性子で有ることを考えれ ば（KEKの実験においては熱中性子が利用されて いた)，強い散乱であれば 1 発での測定も可能で ある。この場合磁場領域としても $60 \mathrm{~T}$ を超える磁 場の利用が可能になると考えられる。J-PARCの ビーム強度が数年で最高值に至る計画であること を考慮すればJ-PARCの開始直後に出来る実験と しては単発パルス磁場を用いた50〜60 Tにおけ る回折実験というのが妥当なところであろう。そ のための検出系としては, パルス中性子で用いら れる PSD 等の分解可能なマルチ検出器が最も適し ている. TOF 方では一回の操作で $\omega$ と $\theta$ の両方を 走査可能である事は大きな利点である。ただし， ビーム強度が最終スペック通りに強くなった場 合, 高係数率に耐えられる検出器をどのように開 
発するかという課題はある。しかしながら中性子 の飛行時間が遅いことを考えれば例えばIPと機 械的なストリーク装置を用いた時間分解測定など も可能であり，多少の不便さをいとわなければ当 面測定を行うのには既存の技術で対応が可能であ る。

\section{JRR-3を用いた R\&D の現状}

最近我々は，X 線用に持ち運び可能なパルス磁 場用コンデンサバンクとミニコイルを組み合わせ て簡便に実験をする手法を開発してきた。現在 JRR-3の AKANE 分光器において, 大山, 加藤ら との協力の元にこのミニコイルを用いた実証実験 を行っている. Fig.2 は，テスト実験で得られた結 果を示す。定常磁場においては，積算されるカウ ント数は積算時間に比例するので，パルス幅が長 い方が有利である。ミニコイルはインダクタンス が小さくてパルス幅が長くできないので，我々は ミニコイルに直列に波形成型用のチョークコイル を回路に入れることでパルス幅を長くすることに 成功した. Fig.2 に改良されたパルス磁場の波形を 示す. 約 100 回の磁場積算で実用的なデー夕を取 ることに成功している [4]. また，この装置の利点 として，通常のオレンジクライオに装着可能であ り，高圧装置と同様なアタッチメントとしての利 用が期待できる事もあげられる。定常炉では単色 中性子を用いるので，TOF と同様の時間分解計測 系を用いることである逆格子空間における回折強 度の磁場依存性を一挙に測定することが可能であ る.さらに最近の結果では $27 \mathrm{~T}$ での中性子散乱実

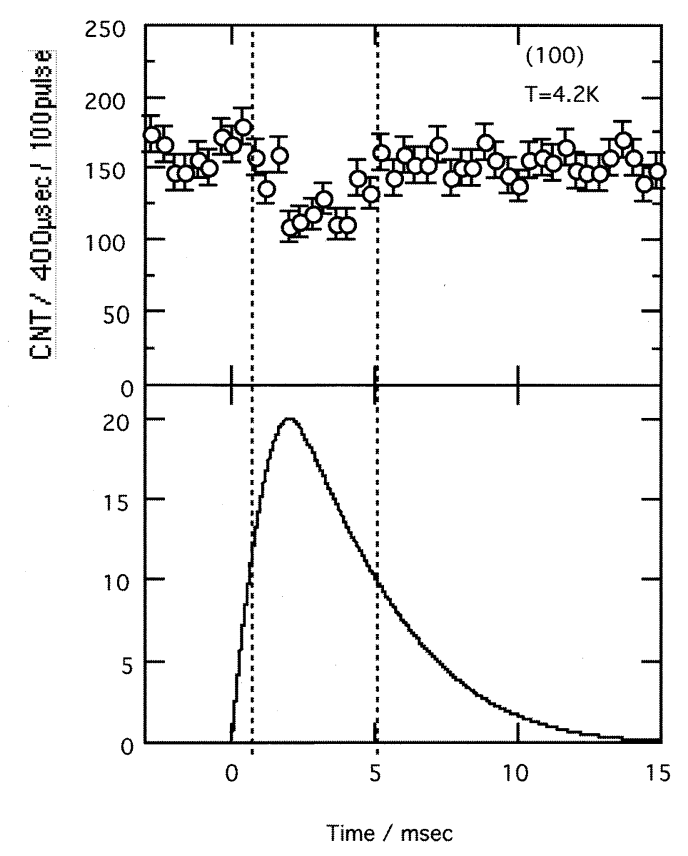

Fig.2 Spectrum of $\mathrm{MnF}_{2}$, average of 100 shots. The intensity of antiferromagnetic (100) peak changes for the spin reorientation at spin flops indicated by dotted lines.
験データの取得に成功しており，論文化にはまだ データの集積を必用とするが, 従来の中性子散乱 実験の世界記録 $25 \mathrm{~T}$ を更新することに成功してい る. 装置としては $40 \mathrm{~T}$ の磁場発生も可能であり, 今後数ヶ月で従来の常識を破る強磁場中の中性子 回折実験に関して出版を予定している。現在最も 改良を迫られているのは，磁場発生間隔の短縮で あり, 現状で $12 \sim 15$ 分程度の間隔を 5 分程度ま で短縮するための改良を施している。ビームの利 用効率をさらに上げるためには，ビームの他の実 験との共有や試料交換機を用いることなどが考え られる [2].

\section{5.まとめ}

以上様々な装置に関して検討をしてきたが，現 時点として単発パルス磁場ベースの中性子回折実 験は，実用的な段階に達しており，技術的困難は 基本的にない. 定常磁場に関しては超電導磁石, ハイブリッド磁石とも技術的にも未知の要素が大 きく, 運営経費の問題も含めて J-PARC の初期に 直ぐ実現する環境にはない. 以上の二つが結論で ある，定常磁場は，高価であるので，当然緻密な “Scientific Case”の検討が求められるであろう。し かしながら，“Science”におけるブレークスルー が予測不可能なものであることを考えれば，その ような検討が容易でないこともまた事実である。 この点を考えれば, 定常磁場の可能性に留意しな がら，まずパルス磁場を先に進めることで，そこ で得られる成果を定常磁場の “Scientific Case” と することが，最も妥当であるというのが私の現時 点での結論である.

最後になるが，我々の J-PARCに対する強磁場 中性子散乱装置提案はパルス磁場から定常磁場ま でを包括的に含み，全ての内外の関係者に対して 開かれている。具体的な実験や装置の提案などを 含めて多くの方の関心と参加を期待したい.

参考文献

[1] 松田 他, 固体物理 40 巻, 11 号 (2005).

[2] H. Nojiri, Neutron News, 12, 279 (2004).

[3] http://www.hfpm.imr.tohoku.ac.jp/

[4] K. Ohyama et al., Proceeding of RHMF2006 (to be published in IOP conference series, 2007, February) 